\title{
O CONTROLE DE CONSTITUCIONALIDADE NO BRASIL: DA CONSTITUIÇÃO DE 1891 AO NOVO CÓDIGO DE PROCESSO CIVIL
}

\section{CONSTITUTIONALITY CONTROL IN BRAZIL: FROM THE 1891 CONSTITUTION TO THE NEW CIVIL PROCESS CODE}

Ilton Garcia Costa ${ }^{1}$

Fioravante Bizigato Junior ${ }^{2}$

Helio Lucas Marques ${ }^{3}$

\section{RESUMO}

Este artigo tem como objetivo analisar, o processo histórico que deu origem ao controle jurisdicional de constitucionalidade no Brasil, de como esse sistema evoluiu até constituição de 1988, e como achegada no Novo Código de Processo Civil influenciou em sua estrutura. Diante disso, busca-se fazer uma análise sobre especificando como funciona e quais foram os modelos em que ordenamento jurídico brasileiro se espelhou, no caso os modelos norte-americano e austríaco, para sua implementação. No que tanque o controle de constitucionalidade após Constituição de 1988, será feito um aprofundamento nas modalidades de controle de constitucionalidade concentrado e controle difuso, bem como serão analisados aspectos de controle preventivo e repressivo que são exercidos pelos Poderes Executivo e Legislativo, e por fim, apontar a notável expansão e evolução do Controle do Difuso, bem como refletir com sua adequação com o Novo Código de Processo Civil, com base na Teoria dos Precedentes Judiciais tornando nesses aspectos mais próximo do controle concentrado de constitucionalidade no tange a eficácias das decisões.

PALAVRAS-CHAVE: Controle de constitucionalidade; Novo Código de Processo Civil; Controle Difuso; Controle Concentrado; Controle preventivo e repressivo.

\footnotetext{
${ }^{1}$ Possui doutorado em Direito pela PUC-SP Pontifícia Universidade Católica de São Paulo, mestrado em Direito pela PUC-SP, mestrado em Administração pelo Centro Universitário Ibero Americano UNIBERO. Graduação em Direito pela Universidade Paulista UNIP. Graduação em Matemática pela Universidade Guarulhos UNG. Especialização em Administração Financeira pela Alvares Penteado, Especialização em Mercados Futuros pela BMF - USP, Especialização em Formação Profissional na Alemanha.

${ }^{2}$ Advogado e consultor jurídico em âmbito preventivo e contencioso, gerenciando projetos diversos. Professor universitário das disciplinas Direito Empresarial, Civil e Processo Civil, com atuação em instituições educacionais de grande porte. Atuação profissional em consultivo/preventivo e contencioso, com ênfase em contratos e direito empresarial. Experiência em contratos internacionais. Redação e conversação em língua inglesa. Palestrante sobre temas de direito empresarial e licenciamento ambiental. Mestrando em direito empresarial e cidadania na Unicuritiba.

${ }^{3}$ Membro do Grupo de Pesquisa Empresarial no Século XXI. linkedin.com/in/helio-lucas-109834173/E-mail: heliolucasmarques@gmail.com
} 


\begin{abstract}
This article aims to analyze the historical process that gave rise to jurisdictional control over constitutionality in Brazil, how this system evolved until the 1988 constitution, and how it came into being in the New Civil Procedure Code influenced its structure. In view of this, we seek to make an analysis of specifying how it works and what were the models in which the Brazilian legal system was mirrored, in this case the North American and Austrian models, for its implementation. Regarding the constitutionality control after the 1988 Constitution, a deepening will be made in the modalities of concentrated constitutionality control and diffuse control, as well as aspects of preventive and repressive control that are exercised by the Executive and Legislative Powers, and finally, point out the remarkable expansion and evolution of the Diffuse Control, as well as reflect its adequacy with the New Code of Civil Procedure, based on the Theory of Judicial Precedents making these aspects closer to the concentrated control of constitutionality in terms of the effectiveness of decisions.
\end{abstract}

KEY WORDS: Constitutionality control; New Civil Procedure Code; Diffuse Control; Concentrated Control; Preventive and repressive control.

\title{
1 INTRODUÇÃO
}

O presente artigo tem por finalidade analisar a história do controle de constitucionalidade no Brasil e sua evolução até o atual modelo. Dessa forma, busca se fazer uma repercussão história, fazendo breves comentários de como se deu a entrada do controle jurisdicional de constitucionalidade qual surgiu no Brasil em 1891, e como esse instituto permaneceu durante as reformas constitucionais no processo de formação do estado brasileiro.

No primeiro capítulo, o leitor será introduzido ao contexto da entrada do controle jurisdicional de constitucionalidade no ordenamento jurídico brasileiro, fazendo um breve explicação qual modelos o Brasil se espelhou para criar o seu modelo de controle no trata-se do modelo norte americano e austríaco, este capitulo ainda dedicado a fazer breves comentários de como o controle de constitucionalidade evoluiu durantes as Constituições anteriores.

No segundo capítulo mostrará como é o atual sistema de controle de constitucionalidade instituído pela Constituição de 1988 e após suas primeiras emendas, adentrado nas modalidades de controle de constitucionalidade: o controle concentrado e o controle difuso, bem como serão abordados o controle preventivo e repressivo feito pelos Poderes Executivo e Legislativo.

Por fim no terceiro e último capítulo, será abordada a última parte do conteúdo do dessa pesquisa. Como o Novo Código de Processo Civil impacta no controle de constitucionalidade, bem como serão os fundamentos que dão ensejo a este tema. Será feita uma breve abordagem dos conceitos dos precedentes judiciais e a sistemática de precedentes introduzidos pelo Novo 
$\mathrm{CPC}$, dando ênfase às suas noções fundamentais e sua compatibilidade com o controle difuso de constitucionalidade, demonstrando a sua possível utilização no ordenamento jurídico brasileiro.

Além disso, será abordado o papel do Senado Federal, bem como e as críticas que este instituto tem recebido, dessa forma será feita uma conclusão do presente estudo mostrando como a Teoria dos Precedentes, pode influenciar no processo de Abstrativização do Controle Difuso de Constitucionalidade.

Nas referências estão inseridas, além de obras diretamente citadas no texto, aquelas que, embora não tenham sido citadas, expressamente, concorreram para a elaboração do presente trabalho.

\section{O SURGIMENTO E EVOLUÇÃO DO CONTROLE DE CONSTITUCIONALIDADE NO BRASIL}

O estado brasileiro durante sua história, passou num total de 6 reformas constitucionais, começou com a Constituição Imperial de $1824^{4}$ e atualmente está sobre a vigência da Constituição de $1988^{5}$. Dentre essas reformas se encontram as Constituições de: 1891, 1934, 1946, 1937, 1965 e 1988. Por aqui a primeira modalidade de controle de constitucionalidade surgiu na Constituição Republicana de 1891 após os trabalhos do jurista Rui Barbosa, um dos responsáveis por elaborar a constituição provisória de 1890, promulgada em 1891, dessa forma inspirado no direito norte-americano surge no Brasil o controle difuso.

O controle difuso surgiu no EUA após o julgamento muito conhecido, o emblemado caso Marbury vs. Madison, que ocorreu no ano 1803, onde a Suprema Corte Americana negou uma ação de Mandado de Segurança impetrado Willian Marbury, um juiz de paz que não conseguiu tomar posse de seu cargo por ordem James Madison, então secretário de estado do presidente eleito Thomas Jefferson.

O pedido de Marbury se baseava no $\S 13$ da Lei do Judiciário de 1789, que instituía competência originaria da Suprema Corte para julgar a referida ação. No qual o relator do caso o juiz John Marshall entendeu que disposto da lei era incompatível com constituição ao instituir

\footnotetext{
4 BRASIL, Constituição Imperial do Brasil. 1824. Disponível em: <http://www.planalto.gov.br/ccivil_03/Constituicao/Constituicao24.htm>. Acesso: 01 de out. de 2019.

5 BRASIL, Constituição da República Federativa do Brasil. 1998. Disponível em: <http://www.planalto.gov.br/ccivil_03/Constituicao/ConstituicaoCompilado.htm>. Acesso: 01 de out. de 2019.
} 
a competência originaria da suprema corte para julgar a ação, pois afrontaria o artigo $3^{\circ}$ da Constituição Norte-americana, acarretando em uma inconstitucionalidade.

O juiz Marshall fundamentou sua decisão, enunciando, fazendo anuência as palavras de Barroso $^{6}$, "os três grandes fundamentos que justificam o controle judicial de constitucionalidade: A supremacia da Constituição, nulidade de lei que contrarie a Constituição, o Poder Judiciário como intérprete final da Constituição’.

Dessa decisão surgiu o controle difuso. $\mathrm{O}$ controle feito pelo poder judiciário de forma incidental no curso de qualquer tipo processual não se tratando a questão constitucional do mérito principal da lide, todavia, levanta-se o conflito de uma norma ou de um ato normativo com o texto constitucional, seja pelo autor, ou pelo réu, ou, até mesmo, pelo próprio juiz, ex ofício.

Desta maneira, a competência para exercer o controle se encontra nas mãos de qualquer juiz ou tribunal, por isso diz-se que o controle de constitucionalidade é difuso (espalhado) e os efeitos da decisão cercam apenas as partes do processo.

Da entrada do controle difuso no ordenamento jurídico brasileiro sua atuação era restrita a competência do Supremo Tribunal federal apenas e precisou ser regulamento pela Lei $\mathrm{n}^{\circ} 221$ de 20 novembro de $1894^{7}$, para que os juízes e tribunais o exercessem a defesa da Constituição, permitindo-lhes deixar de aplicar leis e regulamentos que lhes parecessem manifestamente incompatíveis com a Constituição.

Em 1934 o estado brasileiro passou pela sua segunda reforma constitucional, trazendo dois importantes mecanismos para o controle difuso, o primeiro deles foi o artigo $\mathrm{n}^{\mathrm{o}}$ que estabeleceu o quórum da maioria absoluta dos membros dos tribunais para as decisões sobre inconstitucionalidade de lei ou ato do Poder Público, hoje conhecida como "clausula de reserva de plenário" e a suspensão do Senado Federal de leis ou atos normativos declarados inconstitucionais pelo Supremo Tribunal Federal.

Pouco tempo depois da reforma de 34 surge o "Estado Novo" de Getúlio Vargas, e todas inovações do controle trazidas pela carta de 34 foram consumidas pelo artigo 96 da então

\footnotetext{
6 BARROSO, Luís Roberto. O controle de constitucionalidade no direito brasileiro: exposição sistemática da doutrina e análise crítica da jurisprudência. 2 ed. rev. e atual. São Paulo: Saraiva, 2006, p. 27

7 BRASIL, Lei $\mathrm{n}^{\mathrm{o}} 221$, de 20 de novembro de 1894. Disponível em: < http://www2.camara.leg.br/legin/fed/lei/1824-1899/lei-221-20-novembro-1894-540367 publicacaooriginal40560-pl.html>. Acesso: 01 de out. de 2019.
} 
Constituição de $1937^{8}$ conhecida como "Constituição Polaca", que restringia à necessidade de aprovação do Presidente da República, que poderia submeter à apreciação da constitucionalidade de lei novamente ao exame do Parlamento.

Observa-se que neste período predominou o autoritarismo, de modo que não houve espaço para a atuação de um controle de constitucionalidade, que, por natureza e definição, tem de ser livre, independente, solto, sem obstáculos.

Com a redemocratização do país, a Constituição de $1946^{9}$ retomou o modelo estabelecido pela Carta de 1934, mantendo as inovações que esta havia trazido e como inovação atribuiu ao Procurador Geral da República representação de inconstitucionalidade perante ao Supremo Tribunal Federal, hipótese essa que posteriormente seria chamada de controle concentrado.

Essa modalidade de controle introduzida na carta de 46 foi inspirada pelo direito austríaco. Na Áustria assim como em outros países europeus não aderiram ao modelo difuso, pois seria entregar a guarda da Constituição ao Poder Judiciário, órgão de pouco prestigio nesses países. Então no 1920 a constituição austríaca consagrou o controle concentrado baseado na doutrina kelseniana criando um Tribunal Constitucional, um órgão independente que não era subordinado a nenhum dos outros poderes (Executivo, Legislativo e Judiciário). Este tribunal era especializado em julgar ações de cunho, exclusivamente, constitucional. Sendo todas as suas decisões possuem efeito erga omnes (para todos), pois atingem todas as pessoas sem fazer qualquer distinção. Portanto a lei que, cujo a decisão seja a declaração de inconstitucionalidade, deixa de existir no ordenamento jurídico.

Sob o regime militar a Constituição de 46 sofreu modificação com o advento da Emenda Constitucional $\mathrm{n}^{\circ} 16$ de 1965, que instituiu a então denominada ação genérica de inconstitucionalidade, enquadrando a competência do Supremo Tribunal Federal no controle concentrado, assim o procurador Geral da República como o único legitimado a propor a ação.

Posteriormente sob o regime militar na vigência da Constituição de 1968 é a adicionada a modalidade de controle concentrado, inspirado pelo modelo austríaco positivado pela primeira vez na história na Constituição Austríaca de 1920. Nesse momento o controle concentrado foi introduzido no ordenamento brasileiro limitando sua atuação ao procurador geral da república.

\footnotetext{
8 BRASIL, Constituição da Republica dos Estados Unidos do Brasil. 1937. Disponível em: < http://www.planalto.gov.br/ccivil_03/Constituicao/Constituicao37.htm>. Acesso: 01 de out. de 2019.

9 BRASIL, Constituição da Republica dos Estados Unidos do Brasil. 1946. Disponível em: < http://www.planalto.gov.br/ccivil_03/Constituicao/Constituicao46.htm>. Acesso: 11 de out. de 2019
} 


\section{O CONTROLE APÓS A CONSTITUIÇÃO DE 1988}

A Constituição de 1988 manteve o então modelo constitucionalidade de forma hibrida (difuso e concentrado), dando ênfase em no controle concentrado que além ter aumentado seus legitimados bem como a quantidade ações diretas.

\section{$2.1 \mathrm{O}$ controle concentrado}

Como abordado anteriormente o controle concentrado após a reforma de 1988 foi o mecanismo de controle de constitucionalidade que sofreu mais alterações junto a emendas constitucionais.

Dessa forma vislumbramos que o no artigo 103 da CF/88 ficou incumbindo de listar os legitimados a propor as ações diretas do controle concentrado perante ao STF, desse modo com a nova redação trazida pela Constituição os legitimados passaram a ser: o Presidente da República; a Mesa do Senado Federal; a Mesa da Câmara dos Deputados; a Mesa de Assembleia Legislativa; o Governador de Estado; o Procurador-Geral da República; o Conselho Federal da Ordem dos Advogados do Brasil; partido político com representação no Congresso Nacional; confederação sindical ou entidade de classe de âmbito nacional.

Com a emenda constitucional $n^{\circ} 45$ de 2004, os estados da federação foram incluídos como legitimados no controle concentrado, nesse caso a redação do artigo 103 da Constituição passou a contar com a Mesas das Assembleias Legislativas dos Estados e do Distrito Federal, bem como os Governadores de Estado e do Distrito Federal como novos legitimados.

Em comparação com a Constituição anterior tratou-se uma verdadeira democratização, visto que tirou o monopólio do Procurador Geral da República em manejar as ações diretas que passou de uma para três.

Nessa mesma linha, outra novidade foi o aumento das ações diretas no controle concentrado, começando pela ação Direta de Inconstitucionalidade (antiga ação genérica de inconstitucionalidade) que visa combater inconstitucionalidade em caráter formal ou material em atos do poder públicos nos âmbitos federal e estadual, agora ganhou a modalidade de Ação Direta de Inconstitucionalidade por Omissão (art. 103, $\S 2^{\circ}$ ), instrumento de controle abstrato cuja finalidade é combater as omissões legislativas inconstitucionais, definidas por Gilmar Mendes ${ }^{10}$, com base na doutrina alemã, como “A inobservância de um dever

\footnotetext{
${ }^{10}$ MENDES, Gilmar. Recurso Especial: e o controle difuso de constitucionalidade. São Paulo: Revista dos Tribunais, 2008, p. 1187.
} 
constitucional de legislar, que resulta tanto de comandos explícitos da Lei Magna como de decisões fundamentais da Constituição identificadas no processo de interpretação".

Além da Ação direta de inconstitucionalidade por omissão a Carta de 88 também trouxe a Ação de Arguição de Descumprimento de Preceito Fundamental (ADPF art. 102, $\S 1^{\circ}$ ). Sua regulamentação, no entanto, só foi possível com a promulgação da Lei 9.882 de $1999^{11}$ que previu as seguintes hipóteses de cabimento: a fim de "evitar ou reparar lesão a preceito fundamental, resultante de ato do Poder Público" (art. $1^{\circ}$, caput); e "quando for relevante o fundamento da controvérsia constitucional sobre a lei ou ato normativo federal, estadual ou municipal, incluídos os anteriores à Constituição"(art. $1^{\text {o }}$, parágrafo único, I).

Trata-se de instituto que veio a suprir duas importantes lacunas do controle concentrado brasileiro a possibilidade a impugnação de ato normativo municipal, não contemplado pelos outros instrumentos de controle abstrato bem como a de atos normativos anteriores à Constituição, que de outra forma só poderiam ser apreciados pelo STF em sede de controle difuso.

Finalizando as ações do controle concentrado em 1993 foi adicionada a emenda constitucional no 3, trazendo a Ação Declaratória de Constitucionalidade (ADC), (art. 102, I, “a”). Diferente das outros ações, a ADC foi instituída com intuito evitar questionamentos a leis feitas pelo governo federal sobre presunção de constitucionalidade, pois o Brasil passava por uma forte crise financeira, nesse caso para conseguir implantar as medidas econômicas planejadas pelo governo, assegurando um mecanismo de controle que viabilizasse sua validade no âmbito constitucional.

Como regra estabelecida desde a Constituição de 1946, as ações do controle concentrado são de competência originaria do Supremo Tribunal Federal, pois diferente do modelo austríaco-europeu, o poder constituinte originário elegeu o STF como órgão brasileiro incumbido de exercer a guarda da Constituição, nos termos do art. 102, I, $a$, III, $a, b, c$ e $\S 1^{\circ}$, da $C F / 88$, que, embora goze de autonomia administrativa, é órgão integrante do Poder Judiciário art. 102, I, CF.

O controle concentrado, para Sérgio Moro ${ }^{12}$, "visa à proteção não de direitos subjetivos, mas da própria integridade da ordem jurídica, com a invalidação de atos normativos incompatíveis com a Constituição"

\footnotetext{
11 BRASIL, Lei No 9.882, de 3 De Dezembro de 1999. Disponível em: <http://www.planalto.gov.br/ccivil_03/leis/19882.htm>. Acesso: 01 de out. de 2019.

${ }^{12}$ MORO, Sérgio Fernando. Jurisdição Constitucional como Democracia. São Paulo: Revista dos Tribunais, 2004, p. 306.
} 
Já para Alexandre de Morais $^{13}$, as competências do STF podem ser divididas em dois grandes grupos, conforme o modo de acioná-lo: originário e recursal.

Desta forma, trata-se de competência originária quando o tribunal é acionado diretamente para se pronunciar sobre uma possível ofensa à Constituição por meio das ações que lhe cabe julgar e processar originariamente. A competência recursal, por sua vez, decorre da atuação da Corte como última instância para julgar recurso de decisão de tribunal inferior sobre matéria constitucional do Estado.

A função precípua de salvaguardar a Constituição é exercida no âmbito da competência originária por meio do julgamento das ações diretas de inconstitucionalidade, das ações de inconstitucionalidade por omissão, das ações declaratórias de constitucionalidade e das arguições de descumprimento de preceito fundamental.

Nesses casos, não há existência de lide, ou seja, independe de qualquer caso concreto o ajuizamento do processo.

As pessoas que detém legitimação para ingressar com essas ações apenas vislumbram eventual violação de dispositivo constitucional por ato normativo infraconstitucional, buscando a sua eliminação do mundo jurídico, sem defender direito próprio ou alheio.

Desta forma, ao realizar o controle da constitucionalidade das leis, o STF verifica a adequação de uma lei ou de um ato normativo com a Constituição sob aspectos formais (observância do processo legislativo especificado na Constituição) e materiais (consonância de conteúdo com os princípios, os direitos e as garantias fundamentais previstas na Carta Magna), dessa forma o julgamento de uma ação na via concentrada não tem partes litigantes, sendo o processo denominado por muitos doutrinadores como um processo abstrato, por essa razão controle concentrado também é chamado de controle abstrato.

Com o resultado o $\S 2^{\circ}$ do art. 102 da Constituição estabelece que os efeitos das decisões em controle concentrado sejam vinculantes e tenha eficácia contra todos. A ressalva mostra-se de fundamental importância, porque garante segurança jurídica em âmbito nacional na medida em que procura evitar decisões divergentes sobre um tema já discutido e avaliado pelo tribunal.

${ }^{13}$ MORAES, Alexandre. Jurisdição Constitucional e Tribunais Constitucionais. São Paulo: Atlas, 2000, p. 220. 


\section{$2.2 O$ controle difuso}

Como explicado no capitulo anterior o controle difuso foi a primeira modalidade de controle jurisdicional a surgir no mundo. Trata-se de um controle amplo, pois pode ser levantado por qualquer uma das partes de um processo judicial (autor, juiz e réu), incluindo um terceiro interessado (litisconsorte, assistente, Ministério Público, opoente, etc.) em qualquer instancia processual (varas, tribunais e o Supremo Tribunal Federal), seja esta relação contemplada pelo direito processual ou pelo próprio direito constitucional, no caso por uma ação constitucional que não esteja contemplada no rol das ações do controle concentrado de constitucionalidade, como Habeas Corpus por exemplo.

Como de um controle exercido pela de via de exceção, por óbvio que a matéria constitucional não é o cerne do litigio, pois se assim fosse, estar-se-ia diante de ação direta de inconstitucionalidade no âmbito do controle concentrado. Sendo assim o que ocorre, no controle é a defesa de um direito que está sendo afetado por causa de uma norma inconstitucional, que no caso isolado não é o objeto da demanda como acontece nas ações diretas, por isso sua incidência se de forma incidental.

Nesse sentido Barroso ${ }^{14}$ explica:

[...] O que a parte pede no processo é o reconhecimento do seu direito, que, todavia, é afetado pela norma cuja a validade se questiona. Para decidir acerca do direito em discussão, o órgão judicial precisará formar um juízo acerca da constitucionalidade ou não da norm. Por isso se diz que a norma constitucional é uma questão prejudicial: porque ela precisará ser decidida previamente como pressuposto lógico e necessário a solução do problema principal.

Com exceção do primeiro grau de jurisdição e aos remédios constitucionais que estabelecem ritos próprios definidos pela lei ou respetivos regimentos internos de tribunais e corte superiores como o Supremo Tribunal Federal, a Constituição estabelece no artigo 97, a cláusula de reserva de plenário inserida na Constituição de 34 que o pleno ou órgão especiais dos tribunais decidam sobre matéria de incidente de arguição de inconstitucionalidade em âmbito dos recursos.

Sobre a cláusula de reserva de plenário Didier Jr. ${ }^{15}$ Afirma que:

14 BARROSO, Luís Roberto. O controle de constitucionalidade no Direito Brasileiro. 2 ed. São Paulo: Saraiva, 2006, p 81

15 DIDIER JR, Fredie. Curso de Direito Processual: teoria da prova, direito probatório, decisão, precedente, coisa julgada e tutela provisória / Fredie Didier Jr; Paula Sarno Braga e Rafael Alexandria de Oliveira -12 ed. Salvador: Ed Jus Podvm, 2018, p 437. 


\begin{abstract}
A cláusula de reserva de plenário é instrumento do controle difuso de constitucionalidade; todavia é exemplo de procedimento objetivo, o que significa dizer que o tribunal, quando for decidir se a lei é constitucional ou não, decidirá a questão abstratamente, em tese (como se estivesse em uma ADI). Tanto é verdade que lei vai analisar tal questão apenas uma vez, pois essa decisão vincula o tribunal para causas similares futuras.
\end{abstract}

Da mesma forma que a cláusula de reserva de plenário Constituição delimitou como competência privativa do Supremo Tribunal Federal o exercício do Controle do Difuso como fim da etapa processual.

Nesse sentido o STF exerce o controle difuso oriundo do direito processual, bem como os remédios constitucionais de competência originaria da Suprema Corte.

Da mesma forma que feito nos tribunais o regimento interno do STF determina a remessa do processo para julgamento do pleno de sede controle difuso, esse é o ditame do artigo 176 do regimento interno do Supremo Federal, vejamos:

\footnotetext{
"Arguida a inconstitucionalidade de lei ou ato normativo federal, estadual ou municipal, em qualquer outro processo submetido ao Plenário, será ela julgada em conformidade com o disposto nos arts. 172 a 174, depois de ouvido o ProcuradorGeral".
}

Porem diferente do ocorre nos tribunais o STF tem prerrogativa de ampliar os efeitos da decisão que em regra são inter-partes, concedendo a eficácia erga ommines, em situações relevante interesse, para estabelecer precedente a ser seguido com intuído de evitar novas ações no mesmo sentido, dessa forma de acordo com art. 52 da constituição que versa sobre as competências do Senado Federal, foi atribuído a competência suspender leis declaradas inconstitucionais em sede controle difuso.

Nesse a decisão do STF em desse de controle difuso que decida por conceder a eficácia vinculante erga ommines, é expedido uma resolução ao Senado Federal para Suspender a lei declarada inconstitucional pela Suprema Corte, esse procedimento assim como outros que serão explicados no próximo capítulo é chamado pelo doutrina como Abstrativização do controle difuso.

\title{
2.30 controle preventivo e o controle repressivo
}

Para concluir a respeito do modelo controle de constitucionalidade, além das hipóteses de atuação do poder judiciário os poderes Legislativo e Executivo para exercer a guarda do 
texto constitucional, sendo esta atuação de resguarda da Constituição, é feita em caráter preventivo e repressivo.

Nesse sentido o Poder Executivos possui ter hipóteses de atuação sendo uma de forma preventiva e duas de forma repressiva. Em sede controle preventivo o art. $66, \S 1^{\circ}$, da $\mathrm{CF}$ determina o poder de veto concedido ao Presidente da República, qual se encontra no final do processo legislativo de um projeto de lei. O Presidente da República é competente para considerar o projeto de lei, no todo ou em parte, inconstitucional, devendo motivar sua decisão, a qual será analisada pelas casas legislativas que haviam aprovado o projeto. Estas, por sua vez, podem ou não rejeitar o veto, pela maioria absoluta de seus membros, em votação secreta na sessão conjunta do congresso nacional.

Com relação as hipóteses de controle repressivo pelo Poder Executivo consistem em deixar de cumprir uma lei ou ato normativo do poder público considere ser inconstitucional e a entrada pela via abstrata em ação direta de inconstitucionalidade.

Quanto a primeira hipótese assiste razão no princípio da Supremacia da Constituição, portanto os três poderes têm o dever de assegurar o cumprimento da Constituição, de modo que, o Poder Executivo pode deixar de aplicar uma lei que considera inconstitucional, bem como expedir determinação àqueles submetidos a seu poder hierárquico, no caso a administração Pública direta ou indireta para que procedessem da mesma forma.

Da mesma forma a segunda hipótese encontra respaldo na legitimação concedida aos chefes do executivo estadual e federal para a propositura da ação direita de constitucionalidade e inconstitucionalidade.

Passando para atribuições do Poder Legislativo no controle de constitucionalidade, em caráter preventivo temo sua principal atuação que se dá na principal no curso do processo legislativo pela Comissão de Constituição e Justiça, que possui como uma de suas atribuições a manifestação acerca das propostas de emenda à Constituição e dos projetos de lei apresentados. Desta forma, os pareceres emitidos devem ser compatíveis com a Constituição. Trata-se de hipótese de controle preventivo, realizado por órgão de natureza política, cuja decisão é passível de revisão pelo plenário da casa legislativa.

Outra forma de atuação do Poder Legislativo dá-se conforme estabelece o art. $62, \S 5^{\circ}$, que concede ao Congresso a incumbência de avaliar previamente o conteúdo das medidas provisórias, as quais devem sujeitar-se aos pressupostos constitucionais.

E como medidas controle repressivo temos as ações diretas, seja a de constitucionalidade ou a de inconstitucionalidade, também podem ser propostas por membros 
do Poder Legislativo, representados pelos órgãos de direção do Poder Legislativo federal e estadual.

Tendo a como última hipótese de atuação por meio do Poder Legislativo na de exercer o poder constituinte derivado, pode ele aprovar Emenda à Constituição para superar uma interpretação dada pelo Supremo Tribunal Federal a uma norma constitucional, conforme descrito no art. 60 e parágrafos da Constituição.

\section{O CONTROLE DE COSNTITUCIONALIDADE COM O NOVO CODIGO DE PROCESSO CIVIL}

Com chegada do Novo Código de Processo civil, houve um novo marco na questão de controle de constitucionalidade, isso porque trouxe à tona novamente a discussão sobre a Teoria da Abstrativização do Controle Difuso que aproxima o controle difuso do controle concentrado com relação a eficácia das decisões.

Vejamos o novo CPC veio com a premissa de trazer mais e efetividade e celeridade aos processo judiciais, para tanto trouxe ao ordenamento jurídico a teoria dos precedentes, dessa forma limitando a atuação dos magistrados de primeiro grau a seguir o posicionamento firmados pelos tribunais e corte superiores, bem como os tribunais são obrigados a respeitar os precedentes das cortes superiores e a cortes superiores ficam vinculadas ao posicionamento do Supremo Tribunal Federal.

Para entender o que é um precedente se trata de uma decisão cuja a hermenêutica jurídica (ratio decidendi) formulada pelo magistrado no fundamento do decisório servirá de paradigma para ações similares.

Nesse sentido Didier ${ }^{16}$ explica que:

\footnotetext{
A ratio decidenti - ou, para os norte-americanos, a holding - são os fundamentos jurídicos que sustentam a decisão; a opção hermenêutica adotada na sentença, sem qual a decisão não teria sido proferida como foi. "A ratio decidenti (...) constitui a essência da tese jurídica suficiente para decidir o caso concreto (rule of law).
}

Dessa forma os precedentes podem ser representados por sentenças, acórdãos, enunciados, sumulas entre outros fixar entendimentos sobre temas jurídicos a serem seguidos pelos órgãos do poder judiciário e pelo poder Executivo.

\footnotetext{
${ }^{16}$ DIDIER, JUNIOR, Curso de Processo Civil vol.2 13ª ed. Jus Podivm. 2018, p.514
} 
O precedente jurídico é composto de vários efeitos, o que para esse artigo serão somente abordados o precedente vinculante e o precedente persuasivo. $\mathrm{O}$ precedente vinculante transparece sua eficácia legal, ou seja, eficácia concedida em lei que no caso o Novo CPC organizou a no ordenamento jurídico em forma hierárquica do próprio Poder Judiciário, ou seja, as decisões prolatadas das instancias de cima tem que ser seguidas pelas instancias inferiores, ocorrendo em omissão a decisão que deixe de cumprir esse requisito, cabendo reclamação constitucional nesse caso.

Com relação o precedente persuasivo é decisão cuja a tese sirva como base para enfrentar o conflito jurídico atual sem estar vinculado a ele, nas palavras de Didier ${ }^{17}$ "como diz o nome não tem eficácia vinculante, possui apenas força persuasiva, na medida em que constitui indício de uma solução racional e socialmente adequada". Logo, nenhum magistrado está obrigado a segui-lo, mas, caso o siga, “é porque está convencido de sua correção". Em outras palavras, eficácia persuasiva é o efeito mínimo de todo precedente.

Dito isso para entender melhor como a teoria dos precedentes impacta no controle de constitucionalidade em especial no controle difuso, o art, 927 do novo CPC estabeleceu um rol de precedentes vinculantes a serem observados de forma obrigatória entre juízes e tribunais e dentre a disposições do deste artigo estão as decisões prolatas em sede controle concentrado de constitucionalidade, ou seja as decisões tomadas em sede de controle concentrado são de observância obrigatória em todo poder judiciário o que diretamente se reflete ao controle difuso uma vez que uma lei declarada inconstitucional no controle concentrado serve de resolução a um eventual arguição em sede controle difuso.

Outro importante aspecto está no controle difuso nos tribunais, quando existe arguição de inconstitucionalidade em sede recurso é feita uma cisão de julgamento, o relator do processo remete processo para julgamento o pleno ou órgão especial do tribunal com relação ao incidente, e após o julgamento do incidente o recurso segue o julgamento de mérito pelo órgão colegiado do tribunal, essa é a inteligência combinada dos artigos 948 e 949 do NCPC.

A inovação trazida neste aspecto está no parágrafo único do artigo 949 qual os órgãos fracionários dos tribunais não submeterão ao plenário ou ao órgão especial a arguição de inconstitucionalidade quando já houver pronunciamento destes ou do plenário do Supremo Tribunal Federal sobre a questão.

O que se verifica é ênfase dada a esse sistema de precedentes uma vez que estabeleceu na clausula de reserva de plenário os próprios precedentes formulados pelo pleno ou órgãos

\footnotetext{
${ }^{17}$ DIDIER, JUNIOR, Curso de Processo Civil vol.2 13 ${ }^{\text {a }}$ ed. Jus Podivm. 2018, p.529
} 
especiais dos tribunais, bem como mais uma vez reintegrou a observância das decisões do Supremo Tribunal Federal.

Dessa a teria dos precedentes passa ter um papel muito importe no controle de constitucionalidade, principalmente do controle difuso uma vez aproximou o controle difuso do controle concentrado quando feito no STF, reforçando a teoria da Abstrativização.

Uma vez que decisões da Suprema corte geram precedentes e mesmo nas decisões de controle concentrado e no controle difuso quando no STF isso porque da mesma forma que emitisse uma tese para resolver um problema jurídico em uma decisão, esse método hermenêutico é usando para enfrentar arguição de uma inconstitucionalidade verificando por óbvio traços de inconstitucionalidade material ou formal e a compatibilidade do ato com a Constituição e seus princípios, ocorre que esses mesmo argumentos podem aproveitados e assim devem ser aproveitados pelas instancias superiores, embora os precedentes matérias difuso não sejam de forma vinculante, mas sim persuasiva.

Dessa forma mesmo que de forma indireta discussão sobre a inconstitucionalidade transcende o caso concreto, alcançando caos análogos mesmo sem se valer da suspensão do ato normativo pelo Senado Federal.

Fato este que o artigo 52, X que atribui a competência do Senado nas decisões do controle difuso no STF vem sofrendo varias criticas tanto da doutrina como dos próprios ministros do STF, dos pontos levantados um dos principais argumentos é o do Ministro Gilmar Mendes ${ }^{18}$ que artigo 52, X teria sofrido uma mutação constitucional, tornando-se apenas um órgão de publicidade, vejamos:

[...] possível, sem qualquer exagero, falar-se aqui de uma autêntica mutação constitucional em razão da completa reformulação do sistema jurídico e, por conseguinte, da nova compreensão que se conferiu à regra do art. $52, \mathrm{X}$, da Constituição de 1988. Valendo-nos dos subsídios da doutrina tradicional constitucional a propósito da mutação constitucional, poder-se-ia cogitar aqui de uma autêntica "reforma da Constituição sem expressa modificação de texto"

Outro ponto que Ministro levanta sobre o art. 52, X em decorrência da Emenda Constitucional 45 de 2004 que adicional o art. 103-A, aferiu a Suprema Corte a prerrogativa de editar sumulas vinculantes, estas que podem versar sobre um entendimento de declaração de inconstitucionalidade de ou ato normativo, não precisaria se recorrer ao disposto do art. 52, X.

${ }^{18}$ G. F. Mendes, O papel do Senado Federal no controle de constitucionalidade: um clássico de mutação constitucional, RIL, 162/165. 
Nesse sentido, Mendes ${ }^{19}$ dispõe:

Não resta dúvida de que a adoção de súmula vinculante em situação que envolva a declaração de inconstitucionalidade de lei ou ato normativo enfraquecerá ainda mais o já debilitado instituto da suspensão de execução pelo Senado. É que essa súmula conferirá interpretação vinculante à decisão que declara a inconstitucionalidade sem que a lei declarada inconstitucional tenha sido eliminada formalmente do ordenamento jurídico (falta de eficácia geral da decisão declaratória de inconstitucionalidade). Tem-se efeito vinculante da súmula, que obrigará a Administração a não mais aplicar a lei objeto da declaração de inconstitucionalidade (nem a orientação que dela se dessume), sem eficácia erga omnes da declaração de inconstitucionalidade.

E como exposto pela teria dos precedentes podem ser compostos sumulas, ou seja, uma sumula vinculante oriunda de um caso em sede controle difuso no STF, indiretamente ganha os efeitos de uma decisão do controle concentrado sem precisar do respaldo do Senado Fedral.

Em outra perspectiva Barroso ${ }^{20}$ fala que papel do Senado federal está ligado por uma razão histórica, que foi mantida no atual diploma, porém com a criação da Ação Genérica de Inconstitucionalidade proposta pela emenda constitucional 16/65, somados com os avanços trazidos pela Constituição de 1988, o papel do Senada Federal ocorreu em um erro histórico:

A verdade é que, com a criação da ação genérica de inconstitucionalidade, pela EC n. 16/65, e com o contorno dado à ação direta pela Constituição de 1988, essa competência atribuída ao Senado tomou-se um anacronismo. Uma decisão do Pleno do Supremo Tribunal Federal, seja em controle incidental ou em ação direta, deve ter o mesmo alcance e produzir os mesmos efeitos. Respeitada a razão histórica da previsão constitucional, quando de sua instituição em 1934, já não há lógica razoável em sua manutenção 384. Também não parece razoável e lógica, com a vênia devida aos ilustres autores que professam entendimento diverso, a negativa de efeitos retroativos à decisão plenária do Supremo Tribunal Federal que reconheça a inconstitucionalidade de uma lei. Seria uma demasia, uma violação ao princípio da economia processual, obrigar um dos legitimados do art. 103 a propor ação direta para produzir uma decisão que já se sabe qual é! Por evidente, o reconhecimento da inconstitucionalidade - seja em controle abstrato, seja pela extensão dos efeitos da decisão em concreto - não afeta, direta e automaticamente, todas as situações preexistentes.

Outros pontos sobre o papel do Senado Federal também levantados pelo autor e pela doutrina no sentido que a atuação do Senado não tem caráter vinculado, mas discricionário, sujeitando-se ao juízo de conveniência e oportunidade da casa legislativa, logo seria um ato político, não sujeito a prazo, podendo o Senado suspender o ato normativo, no todo ou em parte,

\footnotetext{
${ }^{19}$ MENDES, Gilmar Ferreira; COELHO, Inocêncio Mártires; BRANCO, Paulo Gustavo Gonet. Curso de Direito Constitucional. 13. ed. rev. e atual. São Paulo: Saraiva, 2018, p.1139.

${ }^{20}$ BARROSO, Luís Roberto. O controle de constitucionalidade no direito brasileiro: exposição sistemática da doutrina e análise crítica da jurisprudência. 2 ed. rev. e atual. São Paulo: Saraiva, 2006, p.100
} 
ou simplesmente não suspendê-lo, ou até podendo se recusar a dar o efeito erga omnes da decisão do Supremo, fato este que comprometeria a eficácia das decisões da Suprema Corte.

Essa competência atípica do Senado somente é exercitável nas hipóteses de declaração incidental de inconstitucionalidade pelo Supremo Tribunal Federal, e não quando a inconstitucionalidade venha a ser pronunciada em sede de ação direta de inconstitucionalidade.

Diante de tais motivos até agora mostrados poder-se-ia compreender que o Novo Código de Processo Civil trouxe dispositivos que demonstram junto à tese de inadequação do art.52, inciso $\mathrm{X}$, da CF ao rito processual, uma vez vista a proximidade recente do controle difuso ao concentrado.

Embora a aplicação da Teoria dos Precedentes ao controle de constitucionalidade possa ocorrer de forma automática principalmente por conta art. 927 do CPC, por ser relevante e eficaz ao processo, sobretudo no que tange à economia processual, à efetividade do processo, à celeridade processual e à implementação do princípio da força normativa da Constituição Federal, como forma de substituir o disputo no art. 52, X da Constituição.

Sua implementação por via doutrinaria e jurisprudencial por analogia as decisões do controle concentrado as decisões do controle difuso não se mostra forma mais correta. Ao entender dessa pesquisa. Vez que estaria usurpando a competência do parlamento que detém a legitimidade como representado da vontade do povo, bem como seria como admitir que o Senado Federal passou a ser órgão de simples publicidade da decisão concreta, em verdadeiro desrespeito à clausula pétrea de separação e autonomia dos poderes.

Desse modo, a forma mais correta ao entender deste trabalho, seria por uma emenda constitucional, por ser mais pertinente e mais legítimo, além de respeitar a segurança jurídica, evitando-se o casuísmo e a insegurança jurídica.

Assim, teme-se que com a adoção da eficácia vinculante no controle difuso, os julgadores apliquem o precedente de forma errada, porquanto esta aplicação decorre de um ato hermenêutico e não mecânico, haja vista a ratio decidendi encontra-se dentro da fundamentação da decisão, portanto a aplicação desde instituto devera-se ser observado e relevância do caso concreto e repercussão nele contida.

\section{CONCLUSÃO}

É inegável a importância que o controle de constitucionalidade tem para ordenamento jurídico brasileiro. Nesse sentido o Brasil Possui um dos modelos mais completos do mundo, pois é a junção de dois mecanismos de guarda da Constituição, um de origem de um 
ordenamento jurídico comum law que modelo norte americano, o controle difuso e forma complementar atotou modalidade controle concentrado baseado na doutrina kelseniana da Áustria.

Como demostrado nesse trabalhado a rigor cada Constituição contribuiu com um mecanismos que ajudou a aperfeiçoar o controle de constitucionalidade, tendo como marco a Constituição de 1988 que manteve o sistema hibrido, trouxe muitas inovações para o controle concentrado, além de possibilitar mais hipóteses de atuação dos Poderes Executivo e Legislativo na guarda do texto constitucional.

Assim no decorrer de pesquisa vislumbrou-se que assim como as leis tendem a evoluir para fazer uma melhor prestação do estado com as necessidades da sociedade, o controle de constitucionalidade também evoluiu para corrigir lacunas e aumentar sua capacidade de atuação entre os três poderes para exercer a supremacia e guarda da Constituição.

Nessa linha vimos que o Novo Códigos de Processo Civil trouxe importantes mecanismos para deixar o controle de constitucionalidade mais célere e efetivo, através do sistema de precedentes positivados no artigo 927 do CPC. Desse mando ampliando o alcance das decisões do controle difuso no Supremo Tribunal federal, tratando da Teoria da Abstrativização, bem como a prerrogativa de edição de sumulas vinculantes pelo STF com intuito de resolver dilemas com relação a questão de inconstitucionalidades de leis ou atos normativos, tratando-se de uma verdadeira expansão dos limites do controle difuso.

Diante disso essa pesquisa para continuar os avanços do controle de constitucionalidade principalmente no que diz respeito ao controle difuso é a reforma no dispositivo do artigo 52, $\mathrm{X}$ para atribuir de forma clara e positiva na Constituição para que a Suprema Corte possa atribuir os efeitos do controle concentrado ao controle difuso se necessário, sem que esta matéria que tenha passar pelo véu do Senado Federal, a fim de ser ter um melhor prestação jurisdicional do estados para com os cidadãos. 


\section{REFERÊNCIAS}

BASTOS, Celso Ribeiro. Curso de Direito Constitucional. 20 ed. São Paulo: Saraiva, 1999. BOBBIO, Norberto. Dicionário de Política. $7^{\text {a }}$ ed. Brasília, Editora Universidade de Brasília, 1995.

BONAVIDES, Paulo. Teoria do Estado. 7 ed. São Paulo: Malheiros, 2008.

BARROSO, Luís Roberto. O controle de constitucionalidade no direito brasileiro: exposição sistemática da doutrina e análise crítica da jurisprudência. 2 ed. rev. e atual. São Paulo: Saraiva, 2006

BRANCO, Paulo Gonet; ROBL FILHO, Ilton Norberto. JUDICIAL REVIEW OF LEGISLATION BY ADMINISTRATIVE BODIES AND NATIONAL COUNCIL OF JUSTICE: LIMITS AND POSSIBILITIES IN DIALOGUE WITH CONSTITUTIONAL JURISDICTION. Revista Juridica, [S.1.], v. 4, n. 57, p. 221 - 248, fev. 2020. ISSN 2316-753X. Disponível em: <http://revista.unicuritiba.edu.br/index.php/RevJur/article/view/3763/371372122>. Acesso em: 20 abr. 2020. doi:http://dx.doi.org/10.21902/revistajur.2316-753X.v4i57.3763.

BRASIL, Constituição Imperial do Brasil. 1824. Disponível em: <http://www.planalto.gov.br/ccivil_03/Constituicao/Constituicao24.htm>. Acesso: 01 de out. de 2019.

BRASIL, Constituição da Republica dos Estados Unidos do Brasil. 1891. Disponível em: < http://www.planalto.gov.br/ccivil_03/Constituicao/Constituicao91.htm>. Acesso: 01 de out. de 2019.

BRASIL, Constituição da Republica dos Estados Unidos do Brasil. 1934. Disponível em: < http://www.planalto.gov.br/ccivil_03/Constituicao/Constituicao34.htm>. Acesso: 01 de out. de 2019.

BRASIL, Constituição da Republica dos Estados Unidos do Brasil. 1937. Disponível em: < http://www.planalto.gov.br/ccivil_03/Constituicao/Constituicao37.htm>. Acesso: 01 de out. de 2019.

BRASIL, Constituição da Republica dos Estados Unidos do Brasil. 1946. Disponível em: < http://www.planalto.gov.br/ccivil_03/Constituicao/Constituicao46.htm>. Acesso: 01 de out. de 2019. 
BRASIL, Constituição da República Federativa do Brasil. 1967. Disponível em: < http://www.planalto.gov.br/ccivil_03/Constituicao/Constituicao67.htm>. Acesso: 11 de out. de 2018.

BRASIL, Constituição da República Federativa do Brasil. 1998. Disponível em: <http://www.planalto.gov.br/ccivil_03/Constituicao/ConstituicaoCompilado.htm>. Acesso: 01 de out. de 2019.

BRASIL, Lei $\mathbf{n}^{\mathbf{0}} \mathbf{2 2 1}$, de 20 de novembro de 1894. Disponível em: < http://www2.camara.leg.br/legin/fed/lei/1824-1899/lei-221-20-novembro-1894-540367 publicacaooriginal-40560-pl.html>. Acesso: 01 de out. de 2019.

BRASIL, Lei $\mathbf{n}^{\mathbf{0}}$ 9.868, de 10 de novembro de 1999. Disponível em: < http://www.planalto.gov.br/ccivil_03/Leis/L9868.htm>. Acesso: 01 de out. de 2019.

CANOTILHO, José Joaquim Gomes. Direito Constitucional e Teoria da Constituição. 7 ed. Sarandi: Almeida, 2011.

DIDIER JR, Fredie. Curso de Direito Processual Volume 2: Teoria da Prova, Direito Probatório, Decisão, Precedente, Coisa Julgada e Tutela Provisória. 12. ed. Salvador: Ed Jus Podvm, 2018.

DIDIER JR, Fredie. Curso de Direito Processual Volume 3: Meios de Impugnação às Decisões Judiciais e Processo Nos Tribunais. 15. ed. Salvador: Ed Jus Podvm, 2018.

KELSEN, Hans. O que é justiça? A justiça, o direito e a política no espelho da ciência. Tradução de Luis Carlos Borges. São Paulo: Martins Fontes, 2001.

KELSEN, Hans. Teoria Geral do Direito e do Estado. São Paulo: Martins Fontes, 1990.

MARINONI, Luiz Guilherme. Novo Código De Processo Civil Comentado. 1.ed. São Paulo, 2015.

MENDES, Gilmar. Recurso Especial: e o controle difuso de constitucionalidade. São Paulo: Revista dos Tribunais, 2008.

MENDES, Gilmar Ferreira; COELHO, Inocêncio Mártires; BRANCO, Paulo Gustavo Gonet. Curso de Direito Constitucional. 13. ed. rev. e atual. São Paulo: Saraiva, 2018.

MIRANDA, Jorge. Teoria do Estado e da Constituição. Rio de Janeiro: Forense, 2002. 
MORAES, Alexandre. Jurisdição Constitucional e Tribunais Constitucionais. São Paulo: Atlas, 2000.

MORO, Sérgio Fernando. Jurisdição Constitucional como Democracia. São Paulo: Revista dos Tribunais, 2004.

NEVES, Daniel Amorim Assumpção. Manual de direito processual civil - volume único, 8 . ed. - Salvador: Ed. Juspodivm, 2016

SILVA, José Afonso. Curso de Direito Constitucional Positivo. 19 ed. São Paulo: Malheiros, 2001.

SOUZA JÚNIOR, Luiz Lopes. A Constituição e seus sentidos: sociológico, político e jurídico? Qual o sentido que melhor reflete o conceito de Constituição? Disponível em http://www.lfg.com.br. 09 de julho de 2009, acesso em 01/11/19

VELOSO, Zeno. Controle Jurisdicional de Constitucionalidade. 3 ed. Belo Horizonte: Del Rey, 2003. 